\title{
Pengaruh Konseling Kelompok Pendekatan Behavioristik Terhadap Penyesuaian Diri Siswa
}

\author{
Nurbaina Siagian ${ }^{1}$ \\ ${ }^{1}$ Bimbingan dan konseling, Universitas Negeri Medan \\ ${ }^{1}$ nurbainasiagian97@gmail.com
}

$\begin{array}{ccc}\text { First received: } & \text { Revised: } & \text { Final Accepted: } \\ \text { 01 Juli } 2020 & \text { 02 September 2020 } & \text { 04 Oktober 2020 }\end{array}$

\begin{abstract}
This study aims to determine the effect of behavioristic approach group counseling services on the adjustment of class VIII-4 students of MTs Negeri 2 Medan. This type of research is Quasi experimental design with Pre test-post test one group design. The population in this study were students of class VIII-4 MTs Negeri 2 Medan T.A. 2019/2020, amounting to 35 people. The sample in this study were 8 students of class VIII-4 with low levels of self-adjustment. The instrument used was a self-adjustment scale of 51 items with a total reliability of 0.465 . From the calculation results, the pretest score in the experimental group obtained an average of $=140$ while the post-test data obtained an average of $=171$. The data were analyzed using the Wilcoxon test to see whether there was a significant effect of group counseling with a behavioristic approach in increasing student adjustment. From the results of the Wilcoxon test shows that the Wilcoxon level test obtained Jcount $=16$ while Jtabel $=4$.From the table the critical value $J$ for the Wilcoxon cascade test for $n=8, \alpha=0.05$ in accordance with the criteria for acceptance and rejection of the hypothesis, the hypothesis is accepted if Jhitung $>$ Jtabel, namely Jhitung $>$ Jtabel where $16>4$, from this calculation it can be seen that the treatment in the experimental group means that the hypothesis that says there is a significant effect of group counseling with a behavioristic approach on the adjustment of class VIII-4 students of MTs Negeri 2 Medan is acceptable.
\end{abstract}

Keywords: Group Counseling, Behavioristic Approaches, Self-Adjustment.

\begin{abstract}
Abstrak
Penelitian ini bertujuan untuk mengetahui pengaruh layanan konseling kelompok pendekatan behavioristik terhadap penyesuaian diri siswa kelas VIII-4 MTs Negeri 2 Medan. Jenis penelitian Quasi experimental dengan design Pre test-post test one group design. Populasi dalam penelitian ini adalah siswa-siswi kelas VIII-4 MTs Negeri 2 Medan T.A. 2019/2020 yang berjumlah 35 orang. Sampel dalam penelitian ini adalah 8 orang siswa kelas VIII-4 yang tingkat penyesuaian dirinya rendah. Instrumen yang digunakan adalah skala penyesuaian diri sebanyak 51 butir item dengan jumlah realibilitas 0,465 . Dari hasil perhitungan diperoleh skor pre-test pada kelompok eksperimen diperoleh rata-rata $=140$ sedangkan data post-test diperoleh rata-rata $=$ 171. Data dianalisis menggunakan uji Wilcoxon untuk melihat adakah pengaruh signifikan pemberian konseling kelompok pendekatan behavioristik dalam meningkatkan penyesuaian diri siswa. Dari hasil uji Wilcoxon menunjukkan bahwa uji jenjang Wilcoxon diperoleh Jhitung $=16$ sedangkan Jtabel $=4$. Dari tabel nilai kritis J untuk uji jenjang bertanda Wilcoxon untuk $n=8, \alpha=0,05$ sesuai dengan kriteria dengan penerimaan dan penolakan hipotesis, hipotesis diterima jika Jhitung $>$ Jtabel yaitu Jhitung > Jtabel di mana $16>4$, dari perhitungan ini dapat dilihat perlakuan pada kelompok eksperimen artinya hipotesis yang berbunyi ada pengaruh signifikan
\end{abstract}


pemberian konseling kelompok pendekatan behavioristik terhadap penyesuaian diri siswa kelas VIII-4 MTs Negeri 2 Medan dapat diterima.

Kata Kunci: Konseling Kelompok, Pendekatan Behavioristik, Penyesuaian Diri.

\section{PENDAHULUAN}

Pendidikan adalah suatu upaya atau perbuatan yang diarahkan pada kemaslahatan dan kesejahteraan peserta didik dan masyarakat sudah berlangsung sejak dahulu dan tidak diragukan lagi eksistensinya. Pendidikan telah mulai dilaksanakan sejak manusia hadir dimuka bumi ini dalam bentuk pemberian warisan pengetahuan, keterampilan, dan nilai-nilai dari para orang tua dalam mempersiapkan anak-anaknya menghadapi kehidupan dan masa depannya yang mampu mengatasi berbagai permasalahan dalam hidupnya.

Pendidikan dapat dipahami sebagai proses melatih peserta didik untuk mengembangkan pengetahuan melalui sejumlah pengalaman belajar sesuai bidangnya dan fikiran, sehingga peserta didik memiliki karakter unggul menjunjung tinggi nilai etis dalam berinteraksi dengan masyarakat sebagai bagian dari pengabdiannya dan dalam memenuhi kebutuhan hidup dirinya maupun keluarganya. Dalam hal ini masih banyak dijumpai permasalahanpermasalahan yang dapat menghambat proses pendidikan, masalah-masalah tersebut banyak dijumpai di sekolah.

Di dalam proses belajar mengajar sangat penting memiliki penyesuaian diri yang baik, siswa yang dapat menyesuaikan dirinya dengan baik di sekolah akan sangat membantu proses belajar mengajar untuk mendapatkan tujuan yang diinginkan. Dengan penyesuaian diri yang baik siswa lebih leluasa menyesuaikan diri dengan lingkungan sekolah, lebih aktif dan ikut serta dalam kegiatan berkelompok maupun itu individu, dan menjadikan siswa mempunyai kemampuan dalam bersosialisasi yang baik.

Penyesuaian diri merupakan masalah yang sedikit banyaknya dialami oleh siswa-siswi di sekolah. Sesuai dengan pendapat Walgito (2002) yang menyebutkan bahwa penyesuaian diri adalah individu dapat meleburkan diri dengan keadaan di sekitarnya dan individu dapat mengubah lingkungan sesuai dengan keadaan dalam diri individu sesuai apa yang di inginkan oleh individu yang bersangkutan.

Seseorang yang mempunyai penyesuaian diri yang baik mampu melakukan respons-respons yang matang, efisien, memuaskan, dan sehat. Dengan memiliki penyesuaian diri yang baik maka ia akan mampu menciptakan dan mengisi hubungan antarpribadi dan kebahagian timbal balik yang mengandung realisasi dan perkembangan kepribadian secara terus menerus. Namun kenyataan yang terlihat dilapangan, masih ditemukan siswa yang memiliki penyesuain diri yang rendah. Hal ini menyebabkan proses belajar mengajar disekolah terhambat dan tujuan yang diinginkan tidak tercapai sepenuhnya. Oleh karena itu, penyesuaian diri yang baik sangat diperlukan oleh setiap siswa untuk mencapai kesuksesan belajarnya.

Penyebab penyesuaian diri yang rendah pada siswa dapat dilihat dari 2 faktor, yaitu faktor internal dan faktor eksternal. Pertama, faktor internal yaitu, faktor yang berasal dari diri individu yang meliputi kondisi jasmani, psikologi, 
kebutuhan, kematangan intelektual, emosional, mental, dan motivasi. Kedua, faktor eksternal yang berasal dari lingkungan yang meliputi lingkungan rumah, keluarga, sekolah, dan masyarakat (Windaniati, 2015:6).

Salah satu cara untuk menerapkan perubahan penyesuaian diri siswa yang rendah dilingkungan sekolah adalah melalui layanan bimbingan dan konseling. Pelayanan bimbingan dan konseling bisa dijadikan sebagai salah satu cara untuk meningkatkan perubahan penyesuaian diri siswa yang rendah dilingkungan sekolah bagi para siswa. Salah satu layanan yang dapat digunakan dalam upaya meningkatkan penyesuaian diri siswa di sekolah adalah dengan layanan konseling kelompok.

Konseling kelompok adalah suatu sistem layanan bantuan yang amat baik untuk membantu pengembangan kemampuan pribadi, pencegahan, dan menangani konflik-konflik antar pribadi atau pemecahan masalah Gazda (dalam Adhiputra, 2015:24 ).

Melalui konseling kelompok, klien akan memperoleh umpan balik berupa tanggapan dan pengalaman klien lain ketika mengatasi masalahnya. Klien yang awalnya memiliki ketakutan untuk mengekspresikan dirinya menghadapi kenyatan akan lebih aktif dalam berinteraksi. Penelitian yang dilakukan oleh Steinmertz, Lewinsohn, dan Antonuccio (dalam Lubis, 2011: 200) menyimpulkan bahwa persepsi individu terhadap potensi dirinya semakin kuat setelah mendapatkan konseling kelompok.

Gladding (dalam Lubis, 2011:168) mengatakan bahwa terapi behavioristik merupakan pilihan utama bagi konselor untuk menangani klien yang menghadapi masalah spesifik seperti gangguan makan, penyalahgunaan obat, dan disfungsi psikoseksual. Selain itu, terapi behavioristik juga dapat digunakan untuk klien dengan gangguan yang dihubungkan dengan kecemasan, stres, asertivitas, dan menjalin interaksi sosial.

\section{KAJIAN TEORI}

\section{Penyesuaian Diri}

Sunarto dan Hartono (2008:221) menyatakan bahwa penyesuaian diri dapat diartikan sebagai penguasaan, yaitu memiliki kemampuan untuk membuat rencana dan mengorganisasi respon-respon sedemikian rupa, sehingga bisa mengatasi segala macam konflik, kesulitan, dan frustasi-frustasi secara efisien. Individu memiliki kemampuan menghadapi realitas hidup dengan cara yang adekuat/memenuhi syarat.

Satmoko (dalam Ghufron dan Risnawita, 2016:50) penyesuaian diri dipahami sebagai interaksi seseorang yang kontinu dengan dirinya sendiri, orang lain, dan dunianya. Seseorang dikatakan mempunyai penyesuaian diri yang berhasil apabila ia dapat mencapai kepuasan dalam usahanya memenuhi kebutuhan, mengatasi ketegangan, bebas dari berbagai simptom yang menggangu (seperti kecemasan kronis, kemurungan, depresi, obsesi, atau gangguan psikosomatis yang dapat menghambat tugas seseorang ), frustasi, dan konflik. Sebaliknya, gangguan penyesuaian diri terjadi apabila seseorang tidak mampu mengatasi masalah yang dihadapi dan menimbulkan respons dan reaksi yang tidak efektif, situasi emosional tidak terkendali, dan keadaan tidak memuaskan. Tinggi rendahnya penyesuaian diri dapat diamati dari banyak sedikitnya hambatan penyesuaian diri. Banyaknya hambatan penyesuaian 
diri mencerminkan kesukaran seseorang dalam penyesuaian dirinya.

Scheneiders (dalam Ali dan Asrori, 2011:173) penyesuaian diri dalam bahasa aslinya dikenal dengan istilah adjustment atau personal adjustment. Membahas tentang pengertian penyesuaian diri, menurut dapat ditinjau dari tiga sudut pandang, yaitu:

1. Penyesuaian diri sebagai adaptasi (adaptation)

2. Penyesuaian diri sebagai bentuk konformitas (conformity)

3. Penyesuaian diri sebagai usaha pengusahaan (mastery)

Tiga sudut pandang tersebut samasama memaknai penyesuaian diri. Akan tetapi, sesuai dengan istilah dan konsep masing-masing memiliki penekanan yang berbeda-beda.

\section{Proses Penyesuaian Diri}

Schneiders (dalam Ali dan Asrori, 2011:176) menyatakan proses penyesuaian diri setidaknya melibatkan tiga unsur, yaitu:

1. Motivasi

2. Sikap terhadap realitas

3. Pola dasar penyesuaian diri

\section{Karakteristik Penyesuaian Diri}

Ali dan Asrori (2011:179) sesuai dengan kekhasan perkembangan fase remaja maka penyesuaian diri di kalangan remaja pun memiliki karakteristik yang khas pula, yaitu:

1. Penyesuaian diri terhadap peran dan identitasnya

2. Penyesuaian diri terhadap pendidikan
3. Penyesuaian diri terhadap kehidupan seks

4. Penyesuaian diri terhadap norma sosial

5. Penyesuaian diri terhada penggunaan waktu luang

6. Penyesuaian diri terhadap penggunaan uang

7. Penyesuaian diri terhadap kecemasan, konflik, dan frustasi

\section{Penyesuaian Diri Yang Baik}

Ali dan Asrori (2011:176) seseorang dikatakan memiliki kemampuan penyesuaian diri yang baik (well adjusted person) jika mampu melakukan responsrespons yang matang, efisien, memuaskan, dan sehat. Dikatakan efisien artinya mampu melakukan respons dengan mengeluarkan tenaga dan waktu sehemat mungkin. Dikatakan sehat arinya bahwa respons-respons yang dilakukannya sesuai dengan hakikat individu, lembaga, atau kelompok antar individu, dan hubungan antara individu dengan penciptanya. Bahkan, dapat dikatakan bahwa sifat sehat ini adalah gambaran karakteristik yang paling menonjol untuk melihat atau menentukan bahwa suatu penyesuaian diri itu dikatakan baik. Dengan demikian, orang yang dipandang mempunyai penyesuaian diri yang baik adalah individu yang telah belajar bereaksi terhadap dirinya dan lingkungannya dengan cara-cara yang matang, efisien, memuaskan, dan sehat, serta dapat mengatasi simptomatik dan gangguan psikosomatik yang mengganggu tujuantujuan moral, sosial, agama, dan pekerjaan. Orang seperti itu mampu menciptakan dan mengisi hubungan antar pribadi dan kebahagiaan timbal balik yang 
mengandung realisasi dan perkembangan kepribadian secara terus-menerus.

Sunarto dan Hartono (2008:224) mereka yang tergolong mampu melakukan penyesuaian diri secara positif ditandai hal-hal sebagai berikut:

1. Tidak menunjukkan adanya ketegangan emosional

2. Tidak menunjukkan adanya mekanisme-mekanisme psikologis

3. Tidak menunjukkan adanya frustasi pribadi

4. Memiliki pertimbangan rasional dan pengarahan diri

5. Mampu dalam belajar

6. Menghargai pengalaman

7. Bersikap realistik dan objektif

\section{Faktor-Faktor Yang Mempengaruhi Penyesuaian Diri}

Schneiders (dalam Ghufron dan Risnawati, 2016:55) berpendapat bahwa dasar penting bagi terbentuknya suatu pola penyesuaian diri adalah kepribadian. Penyesuaian diri merupakan dinamika kepribadian sehingga pembahasan determinasi penyesuaian diri tidak lepas dari penyesuaian diri pembahasan determinasi kepribadian. Perkembangan kepribadian pada dasarnya dipengaruhi oleh interaksi fakta internal dan eksternal individu.

Sunarto dan Hartono (2008:229) berpendapat bahwa secara keseluruhan kepribadian mempunyai fungsi sebagai penentu primer terhadap penyesuaian diri. Penentu berarti faktor yang mendukung, mempengaruhi, atau menimbulkan efek pada proses penyesuaian. Secara sekunder proses penyesuaian ditentukan oleh faktorfaktor yang menentukan kepribadian itu sendiri baik internal maupun eksternal. Penentu penyesuaian identik dengan faktor-faktor yang mengatur perkembangan dan terbentuknya pribadi secara bertahap. Penentu-penentu itu dapat dikelompokkan sebagai berikut:

1) Kondisi-kondisi fisik, termasuk di dalamnya keturunan, konstitusi fisik, susunan saraf, kelenjar, dan sistem otot, kesehatan, penyakit, dan sebagainya.

2) Perkembangan dan kematangan, khususnya kematangan intelektual, sosial, moral, dan emosional.

3) Penentu psikologis, termasuk di dalamnya pengalaman, belajarnya, pengkondisian, penentu diri (selfdetermination), frustasi, dan konflik

4) Kondisi lingkungan, khususnya keluarga dan sekolah

5) Penentu kultural, termasuk agama

Pemahaman tentang faktor-faktor ini dan bagaimana fungsinya dalam penyesuaian merupakan syarat untuk memahami proses penyesuaian, karena penyesuaian tumbuh dari hubunganhubungan antara faktor-faktor ini dan tuntutan individu.

Secara garis besar faktor-faktor yang mempengaruhi penyesuaian diri dibedakan menjadi dua. Pertama, faktor internal yaitu, faktor yang berasal dari diri individu yang meliputi kondisi jasmani, psikologi, kebutuhan, kematangan intelektual, emosional, mental, dan motivasi. Kedua, faktor eksternal yang berasal dari lingkungan yang meliputi lingkungan rumah, keluarga, sekolah, dan masyarakat Ghufron dan Risnawita (2016:55).

\section{Konseling Kelompok}


Winkel dan Hastuti (2006:589) konseling kelompok merupakan bentuk khusus dan layanan konseling, yaitu wawancara konseling antara konselor profesional dengan beberapa orang sekaligus yang bergabung dalam suatu kelompok kecil.

Gazda (dalam Lubis, 2011:198) konseling kelompok merupakan hubungan antara beberapa konselor dan beberapa klien yang berfokus pada pemikiran dan tingkah laku yang disadari. Ia menyatakan bahwa konseling kelompok ini bertujuan untuk memberikan dorongan dan pemahaman pada klien untuk memecahkan masalahnya.

Nurihsan (dalam kurnanto, 2013:7) konseling kelompok adalah suatu bantuan kepada individu dalam situasi kelompok yang bersifat pencegahan dan penyembuhan, serta diarahkan pada pemberian kemudahan dalam perkembangan dan pertumbuhannya.

Latipun (dalam Lubis, 2011:198) menambahkan bahwa konseling kelompok adalah bentuk konseling yang membantu beberapa klien normal yang diarahnya mencapai fungsi kesadaran secara efektif. Konseling kelompok biasanya dilakukan untuk jangka waktu pendek atau menengah.

\section{Pendekatan Behavioristik}

Corey (2013:195) behaviorisme adalah suatu pandangan ilmiah tentang tingkah laku manusia. Dalil dasarnya adalah bahwa tingkah laku itu tertib dan bahwa eksperimen yang dikendalikan dengan cermat akan menyingkap hukum-hukum yang mengendalikan tingkah laku. Behaviorisme ditandai oleh sikap membatasi metode-metode dan prosedurprosedur pada data yang dapat diamati
Gladding (dalam Lubis, 2011:168) mengatakan bahwa terapi behavioristik merupakan pilihan utama bagi konselor untuk menangani klien yang menghadapi masalah spesifik seperti gangguan makan, penyalahgunaan obat, dan disfungsi psikoseksual. Selain itu, terapi behavioristik juga dapat digunakan untuk klien dengan gangguan yang dihubungkan dengan kecemasan, stres, asertivitas, dan menjalin interkasi sosial.

Lubis (2011:167) adapun aspek penting dari terapi behavioristik adalah bahwa perilaku dapat didefinisikan secara operasional, diamati, dan diukur. Para ahli behavioristik memandang bahwa gangguan tingkah laku adalah akibat dari proses belajar yang salah. Oleh karena itu, perilaku tersebut dapat diubah dengan mengubah lingkungan lebih positif sehingga perilaku menjadi positif pula. Perubahan tingkah laku inilah yang membarikan kemungkinan dilakukannya evaluasi atas kemajuan klien secara lebih jelas.

Corey (2013:196) menyebutkan ciri khas terapi behavioristik sebagai berikut:

1. Berfokus pada tingkah laku yang tampak dan spesifik

2. Cermat dan jelas dalam menguraikan treatment

3. Perumusan prosedur treatment dilakukan secara spesifik dan sesuai dengan masalah klien

4. Penafsiran hasil-hasil terapi dilakukan secara objektif

\section{METODE}

Jenis penelitian yang digunakan adalah penelitian quasi experimen (eksperimen semu). Penelitian ini menunjukkan eksperimen yang kurang 
sepenuhnya dapat melakukan kontrol. Dalam penelitian ini, kurang terkontrol dalam prosedur pengumpulan data, misalnya dalam hal kapan dilakukan pengukuran siapa yang dikenai pengukuran tersebut, apakah melakukan random atau tidak melakukannya (Arikunto, 2009:207).

Validitas rumus yang digunakan adalah korelasi Product Moment sebagai berikut:

$$
r_{x y}=\frac{N \sum x y-\left(\sum x\right)\left(\sum y\right)}{\sqrt{\left\{N \sum x^{2}-\left(\sum x\right)^{2}\right\}\left\{N \sum y^{2}-\left(\sum y\right)^{2}\right\}}}
$$

(Arikunto, 2009: 327)

\section{Keterangan :}

$r_{x y}:$ Koefisien Korelasi

$N$ : Jumlah responden

$x$ : Skor responden untuk tiap item

$y$ : Total skor tiap responden dari seluruh item

Sedangkan Dalam menghitung uji reliabilitas dari angket pada penelitian ini menggunakan rumus koefisien alpha sebagai berikut:

$$
r_{11}=\left(\frac{n}{n-1}\right)\left(1-\frac{\sum \sigma_{b}^{2}}{\sigma_{t}^{2}}\right)
$$

(Arikunto, 2009:180)

Keterangan :

$r_{11}:$ Realibilitas instrumen

$n$ : Banyaknya butir soal

$\sigma_{b}^{2}:$ Jumlah varians butir

$\sigma_{t}^{2}:$ Varians total

Selanjutnya dengan membandingkan r11 hasil perhitungan dengan rtabel. Jika rhitung $\geq$ rtabel dapat disimpulkan bahwa butir angket tersebut memenuhi reliabilitas. Untuk menguji hipotesis diatas dengan taraf nyata $\alpha=0,05$ kita bandingkan $\mathrm{J}$ diatas dengan $\mathrm{J}$ yang diperoleh dari daftar tabel uji Wilcoxon, maka H0 di tolak dan sebaliknya, apabila J dari perhitungan lebih besar dari daftar tabel uji wilcoxon maka $\mathrm{H} 0$ diterima artinya bahwa ada pengaruh pemberian layanan

Konseling Kelompok Pendekatan Behavioristik Terhadap Penyesuaian Diri Siswa kelas VIII di MTs N 2 Medan Tahun Ajaran 2019/2020.

\section{HASIL PENELITIAN DAN PEMBAHASAN}

Gambaran umum penyesuaian diri siswa kelas VIII-4 yang diungkap melalui angket penyesuaian diri didapatkan data bahwa 8 orang siswa memiliki skor rendah, dan data ini didapatkan dari penyebaran angket yang dilakukan pada 35 orang siswa. Hal ini menunjukan bahwa tingkat penyesuaian diri siswa kelas VIII-4 harus diberikan perlakuan yang tepat.

Pada penelitian ini dilakukan layanan konseling kelompok pendekatan behavioristik pada siswa kelas VIII-4 yang berjumlah 8 orang untuk meningkatkan penyesuaian dirinya. Berikut gambaran peningkatan penyesuaian diri siswa sebelum diberikan perlakuan dan setelah diberikan perlakuan:

1. Penyesuaian diri siswa AFL mendapatkan skor pre-test (sebelum diberi perlakuan) sebesar 142 dengan kategori rendah dan skor post-test (setelah diberi perlakuan) diperoleh skor sebesar 166 dengan kategori sedang. Maka AFL mengalami selisih skor penyesuaian diri sebesar 24 , artinya 
AFL mendapatkan peningkatan penyesuaian diri sebesar $16,90 \%$.

2. Penyesuaian diri siswa AMC mendapatkan skor pre-test (sebelum diberi perlakuan) sebesar 146 dengan kategori rendah dan skor post-test (setelah diberi perlakuan) diperoleh skor sebesar 176 dengan kategori tinggi. Maka AMC mengalami selisih skor penyesuaian diri sebesar 30, artinya AMC mendapatkan peningkatan penyesuaian diri sebesar 20,54 \%.

3. Penyesuaian diri siswa FA mendapatkan skor pre-test (sebelum diberi perlakuan) sebesar 127 dengan kategori rendah dan skor post-test (setelah diberi perlakuan) diperoleh skor sebesar 169 dengan kategori tinggi. Maka FA mengalami selisih skor penyesuaian diri sebesar 42 , artinya FA mendapatkan peningkatan penyesuaian diri sebesar 33,07 \%.

4. Penyesuaian diri siswa MFR mendapatkan skor pre-test (sebelum diberi perlakuan) sebesar 141 dengan kategori rendah dan skor post-test (setelah diberi perlakuan) diperoleh skor sebesar 173 dengan kategori tinggi. Maka MFR mengalami selisih skor penyesuaian diri sebesar 32, artinya MFR mendapatkan peningkatan penyesuaian diri sebesar $22,69 \%$.

5. Penyesuaian diri siswa RP mendapatkan skor pre-test (sebelum diberi perlakuan) sebesar 136 dengan kategori rendah dan skor post-test (setelah diberi perlakuan) diperoleh skor sebesar 165 dengan kategori sedang. Maka RP mengalami selisih skor penyesuaian diri sebesar 29, artinya RP mendapatkan peningkatan penyesuaian diri sebesar 21,32\%.

6. Penyesuaian diri siswa SRA mendapatkan skor pre-test (sebelum diberi perlakuan) sebesar 144 dengan kategori sedang dan skor post-test (setelah diberi perlakuan) diperoleh skor sebesar 183 dengan kategori tinggi. Maka SRA mengalami selisih skor penyesuaian diri sebesar 39, artinya SRA mendapatkan peningkatan penyesuaian diri sebesar $27,08 \%$.

7. Penyesuaian diri siswa VAT mendapatkan skor pre-test (sebelum diberi perlakuan) sebesar 145 dengan kategori rendah dan skor post-test (setelah diberi perlakuan) diperoleh skor sebesar 174 dengan kategori tinggi. Maka VAT mengalami selisih skor penyesuaian diri sebesar 29 , artinya VAT mendapatkan peningkatan penyesuaian diri sebesar $20 \%$.

8. Penyesuaian diri siswa ZAS mendapatkan skor pre-test (sebelum diberi perlakuan) sebesar 139 dengan kategori rendah dan skor post-test (setelah diberi perlakuan) diperoleh skor sebesar 168 dengan kategori tinggi. Maka ZAS mengalami selisih skor penyesuaian diri sebesar 29 , artinya ZAS mendapatkan peningkatan penyesuaian diri sebesar 20,86 \%.

Secara keseluruhan dari 8 orang responden, diperoleh skor total pre-test (sebelum diberi perlakuan) sebesar 1120, dan skor total post-test (setelah diberi perlakuan) diperoleh sebesar 1374, dengan selisih skor total penyesuaian diri yaitu sebesar 254, maka terjadi peningkatan 
penyesuaian diri sebesar $22,67 \%$. Adapun skor tertinggi pre-test (sebelum diberi perlakuan) diperoleh sebesar 146, dan skor tertinggi post-test (setelah diberi perlakuan) diperoleh sebesar 183, dengan selisih skor penyesuaian diri tertinggi yaitu sebesar 37, maka terjadi peningkatan penyesuaian diri sebesar 33,07\%. Sedangkan skor terendah pre-test (sebelum diberikan perlakuan) diperoleh sebesar 127, dan skor terendah post-test (setelah diberi perlakuan) diperoleh sebesar 165, dengan selisih skor penyesuaian diri terendah yaitu sebesar 38, maka terjadi peningkatan penyesuaian diri sebesar $20 \%$. Dengan demikian maka diperoleh skor rata-rata pre-test (sebelum diberi perlakuan) yaitu sebesar 140 dan skor ratarata post-test (setelah diberi perlakuan) sebesar 171,75 dengan selisih skor rata-rata penyesuaian diri yaitu sebesar 31,75 maka terjadi peningkatan penyesuaian diri sebesar $22,67 \%$.

\section{SIMPULAN}

Berdasarkan hasil penelitian ditunjukan dengan analisis data dan pembahasan maka peneliti dapat menyimpulkan bahwa Terdapat Pengaruh Layanan Konseling Kelompok Pendekatan Behavioristik Terhadap Penyesuaian Diri Siswa Kelas VIII MTs Negeri 2 Medan Tahun Ajaran 2019/2020, artinya hipotesis diterima. Hal ini dapat dilihat dari hasil analisis data dalam penelitian ini, yaitu Jhitung=16, dengan $\alpha=0,05$ dan $\mathrm{n}=8$, maka berdasarkan daftar, Jtabel $=4$. Dari data tersebut terlihat bahwa Jhitung > JTabel dimana $16>4$, artinya hipotesis diterima. Data yang dapat memperkuat adanya peningkatan skor penyesuaian diri adalah dengan melihat skor pre-test diperoleh rata-rata 140, sedangkan data post-test setelah diberikan perlakuan konseling kelompok pendekatan realitas diperoleh rata-rata sebesar 171,75 . Artinya skor rata-rata siswa setelah mendapat layanan konseling kelompok pendekatan behaviorsitik lebih tinggi daripada sebelum mendapat layanan konseling kelompok pendekatan behaviorsitik. Perubahan peningkatan interval penyesuaian diri setelah diberi layanan konseling kelompok pendekatan behaviorsitik sebesar 22,67\%. Hal ini menunjukkan adanya pengaruh layanan konseling kelompok pendekatan behaviorsitik terhadap penyesuaian diri siswa kelas VIII-4 di MTsN 2 Medan T.A 2019/2020.

Dengan adanya pengaruh layanan konseling kelompok pendekatan behavioristik terhadap penyesuaian diri siswa, maka layanan konseling kelompok pendekatan behavioristik merupakan salah satu Teknik dalam BK yang dapat meningkatkan penyesuaian diri siswa

\section{DAFTAR PUSTAKA}

Adhiputra, Ngurah. (2015). Konseling Kelompok: Perspektif Teori dan Aplikasi. Yogyakarta: Media Akademi.

Ali, Mohammad dan Mohammad Asrori. (2011). Psikologi Remaja. Jakarta : Bumi Aksara.

Arikunto, Suharsimi. (2002). Prosedur Penelitian. Jakarta : Rineka Cipta.

Corey, Gerald. (2013). Teori dan Praktek Konseling dan Psikoterapi : Rafika Aditama.

Ghufron, Muhammad Nur dan Rini Risnawati S. (2016). Teori-teori Psikologi. Yogyakarta: Ar-Ruzz Media.

Kartono, Kartini. (2011). Patologi Sosial. Jakarta: Rajawali Pers. 
Kurnanto, Muhammad Edi. (2013). Konseling Kelompok. Bandung: Alfabeta.

Lubis, Namora Lumongga. (2011). Memahami Dasar-dasar Konseling dalam Teori dan Praktik. Jakarta: Kencana Prenada Media Group.

Setiadi, Elly M dan Usman Kolip. (2011). Pengantar Sosiologi (Pemahaman Fakta dan Gejala Permasalahan Sosial: Teori, Aplikasi, dan Pemecahannya ).

Nur aini dkk. (2014). Pengembangan Model Bimbingan Kelompok dengan Teknik Sosiodrama untuk Meningkatkan Penyesuaian Diri Siswa. Jurnal Bimbingan Konseling, 105.

Purwanto, Nanang. (2014). pengantar Pendidikan. Yogyakarta: Graha Ilmu. Sagala,

Syaiful. (2013). Etika dan Moralitas Pendidikan (peluang dan tantangan). Jakarta: Kencana Prenada Media Group.

Sugiono, (2011). Metode Penelitian Administrasi. Bandung: Alfabeta

Sugiono, (2015). Metode Penelitian Pendidikan. Bandung: Alfabeta

Sunarto dan Agung Hartono. (2008). 76 Perkembangan Peserta Didik. Jakarta: Rineka Cipta.

Windaniati. (2015). Meningkatkan Kemampuan Penyesuaian Diri Siswa Melalui Teknik Cognitive Restructuring Pada Kelas X TKR I SMK NEGERI 7 Semarang tahun 2012/2013. Jurnal Penelitian Pendidikan, 2.

Winkel dan Sri Hastuti. (2006). Bimbingan dan Konseling Di Institusi pendidikan. Yogyakarta: Media Abadi. 